\title{
Impact of Financial Risk on Business Efficiency Listed on The Stock Market in Vietnam
}

\author{
Thi Nguyet Dung Nguyen, Thanh Cong Ha, \\ Manh Cuong Nguyen and Thi Thu Loan Bui \\ Faculty of Business Management \\ Hanoi University of Industry, Viet Nam \\ Cau Dien Street, North Tu Liem District, Ha Noi, Viet Nam \\ \{dungntn, conght, nguyenmanhcuong and loanbtt\}@haui.edu.vn
}

\begin{abstract}
This study aims to evaluate the influence of financial risk on the business efficiency of listed companies in Vietnam's stock market. To carry out the research objective, the authors use the short-run solvency, net working capital, and financial risk criteria proposed by Bathory (1984). At the same time, the authors conducted a quantitative analysis using a twostep GMM model, based on panel data collected from financial statements and financial statements of $\mathbf{4 3 0}$ companies listed on the Ho Chi Minh Stock Exchange and the Hanoi Stock Exchange in the period 2012-2018. The research results show that the business efficiency of enterprises through return on assets and return on equity is positively affected by net working capital and financial risk and is negatively impacted by short-run solvency. This result also has some implications for improving business efficiency and financial risk management of listed companies on the Vietnam stock market.
\end{abstract}

Index Terms-Financial risk, business efficiency, net working capital, return on assets, return on equity

\section{INTRODUCTION}

$\mathrm{I}$ $\mathrm{N}$ ADDITION to capital structure decisions, investment decisions, and cash flow decisions, financial risk management decisions have been considered a great concern of enterprise financial management. According to [3], [14], financial risk is an unexpected or unpredictable change in return. According to [1], [12], financial risk is the probability that a business will fail when it uses debt to meet its financial commitments when the cash balance is insufficient. Financial risk has often influenced by factors beyond the control of the enterprise [13], such as interest rates, exchange rates, or developments in financial markets [27]. [30], [18] hypothesize that the degree of risk has a direct impact on potential returns, financial risk can bring the possibility of pleasant surprises or negative business efficiency. High or low business efficiency is affected by the financial risk that the entrepreneur is facing [22], [7], [8], [25].

Although studies on the impact of financial risks on business efficiency of enterprises have been studied by many scientists around the world and received considerable attention from policymakers. However, for a developing economy like Vietnam, research on this topic is still scarce. This study aims to supplement empirical evidence on business efficiency from the perspective of the financial risk of listed companies in Vietnam's stock market. The results of this study are information to help corporate financial managers come up with solutions to improve their business efficiency. Some previous studies on financial risk often measure financial risk through three components: credit risk, liquidity risk, and operational risk. This article approaches financial risk from three angles, namely solvency, operating ability, and financial risk in general, based on the proposal of [4]. To solve the endogenous phenomenon in data analysis and processing, especially in linear dynamic table models, we used a two-step GMM (S-GMM) model on Stata 15.0 software.

The continuous parts of this study include: section 2 is theoretical and empirical results; section 3 presents research models and methods; section 4 focuses on the discussion of research results; section 5 is the conclusion and direction for further research.

\section{Theoretical and Empirical Results}

\section{A. Financial risks}

Financial risk is one of the major concerns of most businesses, so there have been quite a few studies on this topic. Depending on the approach in each study, financial risk can be expressed differently to a certain extent.

For example, some scientists think that financial risk is the possibility of not paying financial debts when they come due [7]. If a firm loses or significantly deteriorates its solvency, the firm may enter a state of financial distress [21]. To measure solvency, [17], [1], [18], [12], [23] have used the short-term solvency ratio (SPR).

$$
S P R=\frac{\text { Short }- \text { term assets }}{\text { Short }- \text { term debt }}
$$

On the other hand, Brigham and Houston (2009) states that financial risk is the uncertainty about the return to owners and the financial balance of the firm. In which the financial balance reflects the relationship between the source of funding and the firm's assets. This means that a company is considered financially balanced when its long-term assets must be sponsored by long-term capital and vice versa. Brigham and Houston (2009) also concluded that the financial risk measurement indicator is a financial balance. And the balanced of finance is expressed through net working capital (NWC).

$$
\begin{aligned}
N W C & =\text { Short term assets }- \text { Short term debt } \\
\text { or } \quad N W C & =\text { Long term capital }- \text { Long term assets }
\end{aligned}
$$

With a multi-dimensional approach, financial risk reflects possible events associated with the choice and implementation of financial decisions that form the asset structure, capital structure, and liquidity capacity from enterprise resources $[4,24,19,25,9]$. And those financial decisions are based on the uncertainty of factors, such as interest rates, exchange rates, developments in financial markets [26]. To measure 
financial risk, these scientists used the FR indicator with five components, specifically as follows:

Where:

$$
F R_{i t}=S Z L_{i t}+S Y_{i t}+G L_{i t}+Y F_{i t}+Y Z_{i t}
$$

$$
S Z L_{i t}
$$$$
\begin{gathered}
=\frac{\text { Profit before taxes }+ \text { depreciation }+ \text { Deferred incom tax }}{S Y_{i t}=\frac{\text { Profit before taxes }}{\text { Shorking capital }}} \\
G L_{i t}=\frac{\text { Shareholders' } \text { interests }}{\text { Short term debt }} \\
Y F_{i t}=\frac{\text { Net Tangible Assets }}{\text { Short term debt }} \\
Y Z_{i t}=\frac{\text { working capital }}{\text { Total assets }}
\end{gathered}
$$

According to [4], $\mathrm{FR}_{\mathrm{it}}$ represents the level of financial risk and financial risk management capacity of the enterprise. If the higher the FR, then the lower the financial risk of the business. It demonstrates the better the financial strength of the business and vice versa.

\section{B. Financial risks}

Business efficiency of the firm is the combined use of resources to realize the economic objectives which can be measured through financial performance [28]. According to [5], [6], business efficiency is the efficiency in using resources of the firm, it is expressed through the relationship between revenue and cost of using input resources. In other words, business efficiency is the ability to turn input resources into the best results in business operations.

The above points of view on efficiency basically all affirm that business efficiency is an indicator that reflects the quality of business operations, the level of use of resources to achieve the ultimate goal, which is maximum profit-making.

To evaluate the business efficiency of firm, [6], [3], [29] has used the following criteria:

- Return on total assets (ROA): ROA indicator is an accurate measure when you want to evaluate the business efficiency of the firm. Because ROA is not only the best indicator to measure the efficiency of all assets invested in the period, but also shows the profitability of the owners and creditors of the business. Therefore, ROA is important for both business owners and operators.

- Return on equity (ROE): ROE indicator reflects how much profit after tax had earned by investment owners for each dollar of capital. Besides ROA, ROE has also been considered an important indicator in assessing the business efficiency of the firms. Because maximizing profits is always the most important goal of business owners.

\section{Impact of financial risk on business efficiency}

The relationship between financial risk and business efficiency has received considerable attention from scientists when studying corporate finance. Many empirical studies have found a statistically significant negative effect of shortterm solvency (SPR) on business efficiency (ROA and ROE) ([1], [12], [23]). As businesses increase their ability to pay their due debts, they must keep high levels of short-term asset items such as cash, receivables, inventory, short-term investments, etc. Meanwhile, these asset items are considered as less profitable items, even the decrease in value or incur costs, thereby reducing business efficiency.

Besides that, some studies have only applied the capital structure theory of Modigliani and Miller (1958) and shown that financial balance has a statistically significant positive effect on financial balance to business efficiency (ROA and $\mathrm{ROE}$ ). When the business has a high financial balance, that is, when all the long-term assets of the business are financed by long-term capital (including equity and long-term liabilities), the efficiency of business results will increase. Because, when a business achieves financial balance, it will not cost the business to find funding when it is insolvent ([29], [1], [12]).

In addition, the impact of financial risk on business efficiency has been explained through agency theory. [16] said that conflicts of interest are always potential between the parties involved, especially the owner (the principal) and the manager (the representative). A conflict of interest arises when a manager uses cash flow to overinvest or put capital in potentially risky projects. These conflicts will increase the financial risks and agency costs of the business. Such as the costs of monitoring and tracking by the owner, binding costs, or losses. To minimize agency costs we have different solutions, such as financial risk management, use of takeover model, use of appropriate capital structure, etc. In particular, financial risk management can be considered as a means to effectively control and minimize agency costs, thereby increasing business efficiency. Financial risk is explained here to include mainly the risk associated with financial decisions that shape the structure of assets, capital structure, solvency from the resources of the firm. With this view, the FR indicator proposed by Bathory [4] is a good indicator to measure the financial risk of enterprises. Because FR is appropriate in emerging market conditions, where credit rating systems are less developed. In addition, the transparency of market information, the ability to access information, and the information infrastructure are still weak ([8], [25], [9]). Thus, if businesses manage risks well, they will help them achieve the goal of maximizing profits.

\section{RESEARCH MODEL AND RESEARCH METHODS}

\section{A. Research model}

Based on agency theory, capital structure theory, and experimental research results of some scientists such as Arif and Showket [1], Fali [12], Onsongo [23], Wangalwa and Muturi [29]. We build a model to study the influence of financial risk on business efficiency as follow:

Model 1:

$R O A_{i t}=\beta_{1} N W C_{i t}+\beta_{2} S P R_{i t}+\beta_{3} F R_{i t}+\beta_{4}$ Size $_{i t}+$ $\beta_{5}$ Age $_{i t}+\beta_{6}$ Grownth $_{i t}+\in_{i t}$

Model 2:

$R O E_{i t}=\beta_{1} N W C_{i t}+\beta_{2} S P R_{i t}+\beta_{3} F R_{i t}+\beta_{4}$ Size $_{i t}+$ $\beta_{5}$ Age $_{i t}+\beta_{6}$ Grownth $_{i t}+\epsilon_{i t}$

In which, the scale of variables in the model is presented in Table I below: 
TABLE I

THE SCALE OF VARIABLES IN THE MODEL

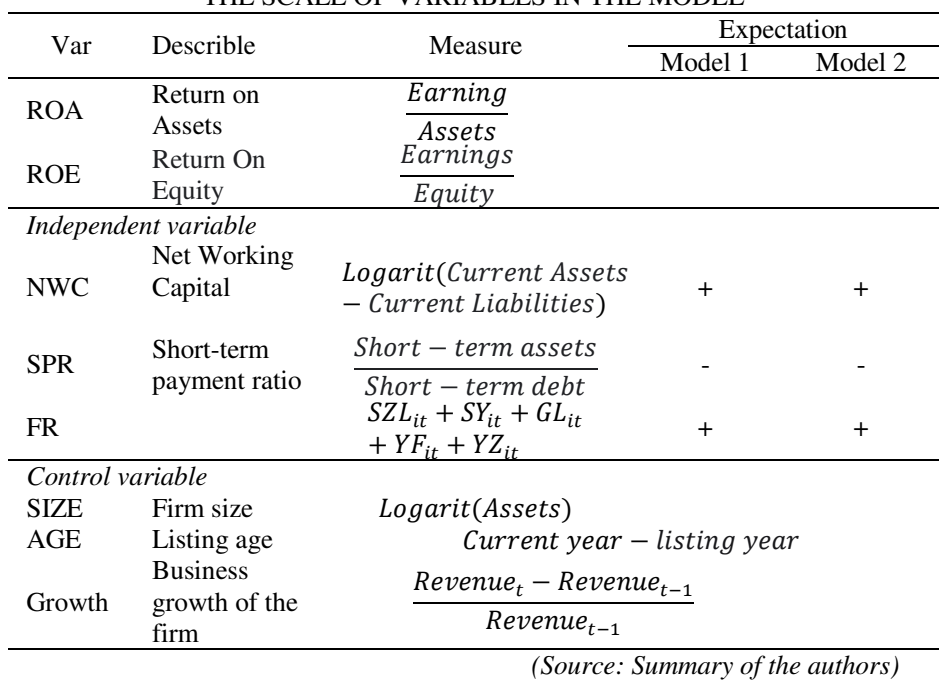

The research hypotheses include:

H1: Short-term solvency (SPR) negatively affects business efficiency.

H2: Net working capital (NWC) positively affects business efficiency.

H3: Overall risk level (FR) positively affects business efficiency.

\section{B. Research methods}

This study performed regression analysis to determine the factors affecting financial risk according to the S- GMM model, using statistical software STATA 15.0 for panel data. At the same time, necessary tests such as the AR test, Sargan test, and Hansen test are performed to ensure that the model does not have heteroskedasticity, autocorrelation, and endogenous. Besides, the S- GMM method is used in regression analysis to determine the coefficients of unbiased, normal distribution, and model efficiency.

Research data is collected from 769 companies listed on the Stock Exchange in the period 2007-2018, provided by FiinGroup - a leading corporate and financial information provider in Vietnam. However, some firms were excluded from the sample due to missing information in panel data. The final sample size includes 430 listed companies during the 7year study period (2012-2018), corresponding to 2,288 observations.

\section{RESULTS}

\section{A. Descriptive statistics}

Descriptive statistics in Table II show that the value of each variable in the model fluctuates quite large. With the independent variable FR, the range is very large, from 0.2569 to 317.6897 , the mean value of FR is 10.2265 . Followed by the variable NWC, the range from 17.9393 to 31.0240 , the mean value is 25.3934 . With the dependent variable ROA, the value of the variable ranges from -0.6455 to 0.4792 , the mean value is 0.0641 . With the dependent variable ROE, the value of the variable ranges from -3.6740 to 0.9539 , the mean value is 0.1059 . Among the control variables, the largest gap in values is the year of listing (Age) variable, the mean value being 10.8858 years, ranging from 7 years to 19 years.

TABLE II

\begin{tabular}{lrrrl}
\multicolumn{5}{c}{ DESCRIPTIVE STATISTICS OF THE VARIABLES } \\
\hline $\begin{array}{c}\text { Variabl } \\
\mathrm{e}\end{array}$ & \multicolumn{1}{c}{ Min } & \multicolumn{1}{c}{ Max } & Mean & $\begin{array}{l}\text { Std. } \\
\text { Dev. }\end{array}$ \\
\hline ROA & -0.6455 & 0.4792 & 0.0641 & 0.0712 \\
ROE & -3.6740 & 0.9539 & 0.1059 & 0.1771 \\
& & 317.689 & 5.0116 & 10.2265 \\
FR & -0.2569 & 7 & 25.393 & 1.6144 \\
NWC & 17.939 & 31.0240 & 4 & \\
SPR & 0.0480 & 61.8349 & 2.2376 & 2.9420 \\
Size & 23.330 & 33.2978 & 27.107 & 1.5258 \\
Age & 3 & 9 & 10.885 & 2.3265 \\
SG & 7 & 19 & 8 & \\
\hline
\end{tabular}

(Source: author's calculation)

\section{B. Regression analysis}

To report the study results, Arellano-Bond and Sargan tests were performed. The results of the tests show that the residuals of the GMM model do not exist 2nd order autocorrelation, Prob > chi2 $=0.311$ (model 1), and 0.136 (model 2). The instrumental variable used in the GMM model is suitable, satisfying over-identifying and overcoming endogeneity with Prob $>$ chi2 $=0.068$ (model 1$)$ and 0.072 (model 2)

The results of 2-step regression with the Hansen coefficient have Prob $>$ chi $2=0.061$ (model 1) and 0.066 (model 2), this result proves that the instrumental variables used in the model all satisfy the tests. Thus, the regression model ensures a stable estimate and a normal distribution. The estimated results are presented in Table III.

TABLE III

IMPACT OF FINANCIAL RISK ON BUSINESS EFFICIENCY

\begin{tabular}{|c|c|c|c|c|}
\hline \multirow{2}{*}{ Variable } & \multicolumn{2}{|c|}{ Model 1 (ROA) } & \multicolumn{2}{|c|}{ Model 2 (ROE) } \\
\hline & Coefficient & Std. Deviation & Coefficient & Std. Deviation \\
\hline $\mathrm{ROA}_{\mathrm{t}-1}$ & $0.0636 * * *$ & 0.0136 & & \\
\hline $\mathrm{ROE}_{\mathrm{t}-1}$ & & & $0.0443 * * *$ & 0.0083 \\
\hline FR & $0.0327 * * *$ & 0.0139 & $0.0722 * * *$ & 0.0275 \\
\hline NWC & $0.0636^{* *}$ & 0.0161 & $0.0134 * * *$ & 0.0036 \\
\hline SPR & $-0.0148 * * *$ & 0.0020 & $-0.0230 * * *$ & 0.0044 \\
\hline SIZE & -0.0357 & 0.0161 & -0.0075 & 0.0046 \\
\hline Growth & $0.0017 * * *$ & 0.0004 & $0.0928 * * *$ & 0.0188 \\
\hline AGE & $-0.0005^{*}$ & 0.0004 & 0.0009 & 0.0007 \\
\hline Constant & $-0.0585 * * *$ & 0.0367 & $-0.2270 * * *$ & 0.0683 \\
\hline \multirow{2}{*}{$\begin{array}{l}\text { Obs. } \\
\mathrm{N}^{\circ} \text { of } \\
\text { firms }\end{array}$} & & 2,288 & & 2,288 \\
\hline & & 430 & & 430 \\
\hline $\begin{array}{l}\operatorname{AR}(2) \\
\text { test (Prob } \\
>\text { chi2) }\end{array}$ & & 0.311 & & 0.136 \\
\hline $\begin{array}{l}\text { Sargan } \\
\text { test (Prob } \\
>\text { chi2) }\end{array}$ & & 0.068 & & 0.072 \\
\hline Hansen tes & (Prob > chi2) & 0.061 & & 0.066 \\
\hline
\end{tabular}


Note: ***, **, * represent $1 \%, 5 \%$, and $10 \%$ significance levels, respectively

The results of the study on the influence of financial risk on the business efficiency of non-financial enterprises listed on the Ho Chi Minh City Stock Exchange and the Hanoi Stock Exchange are as follows:

- Liquidity (through the indicator Short-term solvency SPR) has a negative impact on ROA and ROE with the coefficient $\beta$ of -0.0148 (significant level $1 \%$ ) and -0.0230 (significant level 1\%), respectively. This shows that, when an enterprise can pay short-term debts from short-term assets, the higher it's business efficiency, the lower its business efficiency, because short-term assets are considered as items of interest less profitable (deposits, short-term investments, ect.) even reduce the value (cash, receivables, ect.) or hidden costs such as storage costs, provision costs, ect. This result also agrees with the research results of Arif and Showket [1], Fali [12], Onsongo [23].

- Financial balance (through Net Working Capital - NWC) has a positive impact on ROA and ROE with the coefficient $\beta$ of +0.0636 (significant level $5 \%$ ) and +0.0134 (significant level $1 \%$ ), respectively. This means that, when the enterprise achieves financial balance, when the long-term assets of the enterprise must be financed by long-term capital and vice versa, the enterprise will not spend any money in seeking funding in case of insolvency. This result is consistent with the capital structure theory as well as the views of Wangalwa and Muturi [29], Arif and Showket [1], Fali [12].

- When considering the factor measuring the level of financial risk through Bathory's FR [4], it can be seen that the direction of the impact of this factor on ROA and ROE are positive with the coefficient $\beta$, respectively are +0.0327 (significant level 1\%) and +0.0722 (significant level 1\%). Meanwhile, according to Bathory [4], the higher the FR, the lower the financial risk of the enterprise, the better the financial risk management capacity. This means that, when an enterprise can limit its FR, its ability to manage financial risks is good, which will help increase its ROA and ROE. This research result is consistent with our explanations in the theoretical basis when applying asymmetric information theory, signal theory, and agency theory.

With the above results, all hypotheses are accepted. A summary of the influence of factors on financial risk are presented in Table 4 as follows:

TABLE IV

SUMMARY OF RESEARCH RESULTS

\begin{tabular}{|c|c|c|c|c|c|}
\hline \multirow{2}{*}{$\begin{array}{c}\text { Independent } \\
\text { variables }\end{array}$} & \multicolumn{2}{|c|}{$\begin{array}{c}\text { Research } \\
\text { hypothesis }\end{array}$} & \multicolumn{2}{|c|}{$\begin{array}{c}\text { Research } \\
\text { results }\end{array}$} & \multirow[t]{2}{*}{ Conclusion } \\
\hline & ROA & ROE & ROA & ROE & \\
\hline $\mathrm{ROA}_{\mathrm{t}-1}$ & & & + & & \\
\hline $\mathrm{ROE}_{\mathrm{t}-1}$ & & & & + & \\
\hline NWC & + & + & + & + & Accepted \\
\hline SPR & - & - & - & - & Accepted \\
\hline FR & + & + & + & + & Accepted \\
\hline SIZE & & & K & $\mathrm{K}$ & \\
\hline Growth & & & + & + & \\
\hline AGE & & & - & - & \\
\hline
\end{tabular}

$\mathrm{K}$ : There is not enough basis to conclude about the relationship

(Source: Summary of the authors)

\section{CONCLUSION AND FUTURE RESEARCH DIRECTIONS}

By quantitative research method with panel data collected from financial statements and annual reports of 430 enterprises listed on the Ho Chi Minh City Stock Exchange and Hanoi Stock Exchange from 2012-2018. The study showed that the business efficiency of the firm (through ROA and ROE indicators) is positively affected by the financial balance (represented by Net Working Capital (NWC) and FR); it is negatively affected by solvency through short-term solvency (SPR).

The findings from the study provide empirical evidence to help corporate financial managers have a basis to propose solutions to improve business efficiency. The results of this paper emphasize that, if risk management is not good, it will reduce the business efficiency of enterprises. Therefore, businesses need to come up with an appropriate risk appetite strategy in corporate financial management activities. At the same time, in order to improve business efficiency and create a financial balance, businesses need to be more cautious when deciding debt maturity in setting up a financial structure.

Based on the obtained results, this study has contributed to enrich the existing literature on financial risk and its impact on business efficiency. However, our approach mainly focuses on studying the internal factors of enterprises. Therefore, future research needs to be expanded with the addition of macro factors such as economic growth, inflation rate, or economic crisis into the model.

\section{REFERENCES}

[1] Arif, A. S., A. (2015). Relationship between financial risk and financia performance: An Insight of Indian Insurance Industry. International Journal of Science and Research, 4(11), 1424-1433. Retrieved from https://papers.ssrn.com/sol3/papers.cfm?abstract id=3553374

[2] Auronen, L. (2003). Asymmetric Information: Theory and Applications. Seminar of Strategy and International Business, 116, 45-56. Retrieved from

https://citeseerx.ist.psu.edu/viewdoc/download?doi=10.1.1.198.9252\&rep $=$ rep $1 \&$ type $=$ pdf

[3] Awunyo, D. \& Badu, J. (2012). Capital Structure and Performance of Listed Banks in Ghana, Global Journal of Human Social Science, 12(5), 3-7

[4] Bansal, A., Kaufmann, R., Mark, R., and Peters. E. (1992). Financial Risk and Financial Risk Management Technology: Issues and Advantages. Working Papers Series, New York, New York University, 1(3), 27 - 34. Retrieved from https://www.managementjournal.info/index.php/IJAME/article/view/173/ 166

[5] Bathory, A. (1984). Predicting Corporate Collapse: Credit Analysis in the Determination and Forecasting of Insolvent Companies. London, UK: Financial Times Business Information: London, UK: Financial Times Business Information.

[6] Berger, A. N., and R. DeYoung. (1997). Problem Loans and Cost Efficiency in Commercial Banks. Journal of Banking and Finance, 21, 849-870. https://doi.org/10.1016/S0378-4266(97)00003-4

[7] Berger, A. N. D. P. (2002). Capital Structure and Firm Performance: A New Approach to Testing Agency Theory and an Application to the Banking Industry. Feds Paper. doi:10.1016/j.jbankfin.2005.05.015

[8] Bhunia A., Mukhuti S., 2012. Financial risk measurement of small and medium-sized companies listed in Bombay Stock Exchange. International Journal of Advances in Management and Economics, 1(3), 27-34. Retrieved from https://www.managementjournal.info /index.php/IJAME/article/view/173/166 
[9] Brigham, E.F. \& Houston, J.F. (2009). Fundamentals of Financial Management (Eleventh Edition). University of Florida, Thomson South-Western, 415-456.

[10] Celli, M. (2015). Can Z-Score Model Predict Listed Companies' Failures in Italy? An Empirical Test. International Journal of Business and Management, 10(3). doi:10.5539/ijbm.v10n3p57

[11] Dandago, K. I. B., B.U. (2014). The Use of Multi-discriminant Analysis for the Prediction of Corporate Bankruptcy in Malaysian Textile Industry. Journal of Business and Economics, 5(6), 813-822. doi: 10.15341/jbe (2155-7950)/06.05.2014/006

[12] Dang T.H., P. T. D., Nguyen T.H., Hoang T.H. (2020). Determinants of Share Prices of Lited Companies Operating in the Steel Industry: An Empirical Case from Vietnam. The Journal of Asian Finance, Economics and Business, 7(12), 131-138. doi:10.13106/jafeb.2020.vol7.no12.131

[13] Dasouqi. A. Q, K. A. K. a. (2017). Sales nationality and debt financing impact on firm's performance and risk Evidence from Jordanian companies. Euro Med Journal of business, 12(1), 103-126. https://doi.org/10.1108/EMJB-05-2016-0015

[14] Dey, R. K., Hossain, S.Z., and Rezaee, Z. (2018). Financial Risk Disclosure and Financial Attributes among Publicly Traded Manufacturing Companies: Evidence from Bangladesh. Journal of Risk and Financial Management, 11(3), 50 https://doi.org/10.3390/jrfm11030050

[15] Fali, I., Nyor, T., Mustapha, L. (2020). Financial Risk and Financial Performance of listed Insurance Companies in Nigeria. European Journal of Business and Management, 12(12), 143-153. doi: 10.7176/EJBM/12-12-13

[16] Harvey, J. (2008). Financial Risk Management, 47th ed. London: The Chartered Institute of Management Accountants.

[17] Holton, G. A. (2004). Defining risk. Financial Analysts Journal, 60, 19-25. doi.org/10.2469/faj.v60.n6.2669

[18] Houston, B. (2009). Fundamentals of Financial Management (Eleventh Edition). University of Florida: Thomson South-Western.

[19] Jensen, M. C., William, H., and Meckling, W.H. (1976). Theory of the Firm: Managerial Behavior, Agency Costs and Ownership Structure. Journal of Financial Economics, 3, 305-360. doi: 10.1016/0304405X(76)90026-X

[20] Khasawneh, A. K \& Dasouqi, A. Q. (2017). Sales nationlity and debt financing impact on firm's performance and risk Evidence from Jordanian companies', EuroMed Journal of business, 12(1), 103-126.

[21] Khurshid, M. R. (2013). Determinants of financial distress evidence from KSE 100 index. Research Journal of the Institute of Business administration Karachi, 8(1), 7-19. Retrieved from https://ir.iba.edu.pk/businessreview/vol8/iss1/2/

[22] Kinyua, J. K., Gakure, R., Gekara, M. and Orwa, G. (2015). Effect of Risk Management on The Financial Performance Of Companies Quoted In The Nairobi Securities Exchange. International Journal of Business \& Law Research, 3, 26-42. Retrieved from https://www.academia.edu/33959612/Effect_Of_Risk_Management On_The_Financial_Performance_Of_Companies_Quoted_In_The_Na irobi Securities Exchange

[23] Kociu, L., Mano, R., \& Armand, H. (2015). Financial Risk Assessment of Albanian SMEs with the Help of Financial Ratios.
European Scientific Journal, 11(4), 309-321. Retrieved from https://core.ac.uk/download/pdf/328024798.pdf

[24] Li, S. (2003). Future trends and challenges of financial risk management in the digital economy. Managerial Finance, 29(5/6), 111-125. doi:10.1108/03074350310768797

[25] Masnoon, M., and Saeed, A. (2014). Capital Structure Determinants of KSE Listed Automobile Companies. European Scientific Journal, 10(13), 451-461. Retrieved from https://papers.ssrn.com/sol3/papers.cfm?abstract id=2444698

[26] Mugozhi, F. (2016). An assessment of the application and the corporate failure predictive value of Altman's Z score model in Zimbabwe. Journal on Business Review, 4(4), 66-74. https://doi.org/10.5176/2010-4804_4.4.398

[27] Modigliani, F. \& Miller, M. H. (1958), /The cost of capital, Coporation finance and the theory of investment, The American Economic Review, 48(3), 261-297.

[28] Onsongo S. K., M. S. M. A., Mwangi L.W. (2020). Financial Risk and Financial Performance: Evidence and Insights from Commercial and Services Listed Companies in Nairobi Securities Exchange, Kenya. International Journal of Financial Studies, 8(51). http://dx.doi.org/10.3390/ijfs8030051

[29] Saeed, M., Gull, A. \& Rasheed, M. (2013). Impact of Capital Structure on Banking Performance (A Case Study of Pakistan). Interdiscilinary Journal of Contemporary Research in Business, 4(10), 5-10

[30] Sharifi, O. (2014). Financial Risk Management for Small and Medium Sized Enterprises. International Journal of Information. Business and Management, $\quad 6, \quad 82-89 . \quad$ Retrieved from https://www.proquest.com/openview/cfaa3f3a850e176b17f7901b8bc7 70f2/1?pq-origsite $=$ gscholar \&cbl $=2032142$

[31] Simantinee S., K. T. V. V. (2015). Factors Influencing Financial RiskA Case Study of NSE NIFTY Companies. International Journal in Management \& Social Science, 3(8), 132-137. Retrieved from https://euroasiapub.org/wp-content/uploads/2016/11/6FMApril-20771.pdf

[32] Spence, M. (2002). Signaling in retrospect and the informational structure of markets. American Economic Review, 92, 434-459. Retrieved from https://www.jstor.org/stable/3083350

[33] Steven, L. (2003). Future trends and challenges of financial risk management in the digital economy. Managerial Finance, 29(6), 111125. doi: $10.1108 / 03074350310768797$

[34] Venkatraman. N, a. V. R. (1986). Measurement of Business Performance in Strategy Research: A Comparison of Approaches. Academy of Management Review, 11(4), 801-814. doi: 10.5465/AMR.1986.4283976

[35] Wangalwa, M. a. M., W. (2018). Effect of Financial Risk on Financial Performance of Large-Scale Supermarkets in Nairobi County, Kenya. International Journal of Social Science and Technology, 4, 574-591. Retrieved from https://www.ijssit.com/main/wp-content/uploads/2018/10/Effect-OfFinancial-Risk-On-Financial-Performance-Of-Large-ScaleSupermarkets-In-Nairobi.pdf

[36] Woods, M., and Dowd, K. (2008). Financial Risk Management for Management Accountants: Oxford: Elsevier. 